ACTA THERIOLOGICA

Vol. 33, 5: 57-65, 1988

\title{
Winter and Early Spring Food of Some Carnivores in the Białowieża National Park, Eastern Poland ${ }^{1}$
}

\author{
Santiago REIG ${ }^{2} \&$ Włodzimierz JĘDRZEJEWSKI
}

Reig S. \& Jędrzejewski W. 1988: Winter and early spring food of some carnivores in the Białowieża National Park, eastern Poland. Acta theriol., 33, 5: 57-65 [With 3 Tables \& 1 Fig.]

Data on the food of the wolf Canis lupus, the lynx Lynx lynx, the red fox Vulpes vulpes, the raccoon dog Nyctereutes procyonoides, and the pine marten Martes martes living in the temperate primeval forest are presented from one winter and early spring season. $91.5 \%$ of the biomass consumed by the five species was made up by mammalian prey. Wolf and lynx specialized in ungulates (red deer and wild boar), the other three species utilized a wide spectrum of resources, with rodents as a staple food. Birds and medium-sized mammals were of small importance in the carnivores' diet. Na clear differences occurred between the winter and spring food of foxes and martens. The diet of foxes and martens was compared with data from other regions of Poland.

[Mammals Research Institute, Polish Academy of Sciences, 17-230 Białowieża, Poland]

\section{INTRODUCTION}

In Europe most research on carnivores has been carried out in more or less intensively settled areas (Ryszkowski et al., 1971; Ryszkowski, Goszczyński \& Truszkowski, 1973; Andersson \& Erlinge, 1977; Erlinge et al., 1983: Guitian \& Callejo, 1983; Goszczyński, 1986). Data on predators in their primeval habitats are scarce and therefore greatly needed for comparison. This paper is a preliminary report on the winter and early spring diets (determined from scats) of carnivores in the Białowieża National Park, the remnant of temperate primeval forests that formerly dominated over the lowlands of Central Europe. We present data on four native species, the wolf Canis lupus Linnaeus, 1758, the lynx Lynx lynx (Linnaeus, 1758), the red fox Vulpes vulpes (Linnaeus, 1758), the pine marten Martes martes (Linnaeus, 1758), and one autointroduced species, the raccon dog Nyctereutes procyonoides (Gray, 1834), in winter 1985/86 and spring 1986 .

1 Praca wykonana w ramach CPBP04.10., koordynowanego przez Szkolę Główną Gospodarstwa Wiejskiego - Akademię Rolniczą w Warszawie.

2 Present address: Unidad de Zoologia Aplicada, Apdo. 127, Alcala de Henares, Madrid, Spain. 


\section{STUDY AREA}

The Bialowieża National Park $\left(23^{\circ} 55^{\prime} \mathrm{E}, 52^{\circ} 45^{\prime} \mathrm{N}\right)$ includes $47 \mathrm{~km}^{2}$ of diverse deciduous, mixed and coniferous forests with oak Quercus robur, linden Tilia cordata, black alder Alnus glutinosa, maple Acer platanoides, hornbeam Carpinus betulus, spruce Picea abies, pine Pinus silvestris, and many other tree species. The swampy, riverflooded, fresh, and fairly dry forest associations make the habitat extremely varied. On its southern border the Park meets cropfields and meadows of the Bialowieża Glade. In the north, east and west the Park joins continuous forests. No cutting or hunting activities take place in the park area. Human penetration is restricted to a few pedestrian paths. A detailed description of forest habitats is given by Faliński (1986).

The other terrestrial predators present in the study area comprised the polecat Mustela putorius Linnaeus, 1758, the stoat $M$. erminea Linnaeus, 1758 , the weasel M. nivalis Linnaeus, 1766, and the badger Meles meles Linnaeus, 1758.

The most important potential prey species were large ungulates (red deer Cervus elaphus, and wild boar Sus scrofa) and rodents, mainly bank voles Clethrionomys glareolus, yellow-necked mice Apodemus flavicollis, and root voles Microtus oeconomus. Forest rodents were very numerous during the study period (W. Jędrzejewski, unpubl.). Fields and meadows adjacent to the Park abounded in common voles Microtus arvalis. Hares Lepus capensis sparsely inhabited the forest. In winter, birds were scarce and comprised year-round residents (mainly jay Garrulus glandarius, hazel hen Tetrastes bonasia, woodpeckers, and small Passeriformes) and small passerine visitors from the north. In spring, migrating birds appeared. April and May was the period of egg-laying and incubation for most small species of birds.

\section{METHODS AND MATERIAL}

Scats were collected from 15 December 1985 to 30 May 1986. The entire material consisted of 15 scats of wolf, 15 of lynx, 76 of red fox, 9 of raccoon dog, and 62 of pine marten. In the case of fox and marten the data were divided into winter (15 Dec. $-30 \mathrm{March}$ ) and early spring (1 April $\rightarrow 30$ May) material. The analysis of scats followed standard procedure (Lockie, 1959). Necessary microscopic examination of hair was done according to Dziurdzik (1973). The contribution of each kind of food to the diet was presented as a percentage of occurrence in the scats, and as a percentage of biomass consumed. In order to estimate the amount of biomass consumed, all the identified remains were weighed separately and multiplied by coefficients of digestibility. To facilitate calculations the coefficients given by Goszczyński $(1974,1976)$ for foxes and martens were applied to all species. The bias of this assumption could be discarded due to the small sample size.

The Shannon's index of diverisity $\bar{H}$ (Shannon \& Weaver, 1949) was used to measure the degree of specialization:

$$
\bar{H}=-\sum_{i}^{\mathrm{n}} p_{\mathrm{i}} \ln p_{\mathrm{i}}
$$

where $p_{1}$ is the proportion of each group of food (expressed as percentage of biomass) in the diet. The lower the value of $\bar{H}$ the higher the specialization. 
Trophic overlapping between four species (raccoon dog was omitted because of very small sample size) was expressed by Pianka's index (Pianka, 1973):

$$
c_{\mathrm{ij}}=\sum_{\mathrm{i}}^{\mathrm{n}} p_{\mathrm{ia}} p_{\mathrm{ja}}\left[\left(\sum_{\mathrm{i}}^{\mathrm{n}} p_{\mathrm{ia}}{ }^{2}\right)\left(\sum_{\mathrm{i}}^{\mathrm{n}} p_{\mathrm{ja}}{ }^{2}\right)\right]^{\frac{1}{2}}
$$

where $p_{\text {ia }}$ was the proportion of food items from ath food group in the total number of items consumed by $i$ th species of predator (for groups of food see Table 1).

\section{RESULTS}

\subsection{Composition of Diets}

The diets of the five species studied are shown in Table 1. Ungulates made up the bulk of the wolf and lynx diet. Rodents were staple food for marten, fox, and raccoon dog. Martens clearly selected forest rodents, i.e. Clethrionomys glareolus and Apodemus sp., whereas foxes preferred Microtus sp. (Table 1). This reflects the differences in the habitat utilization by both species: pine martens were restricted to the forest and foxes penetrated more the edges of the forest and the adjacent open areas (cf. Goszczyński, 1985). Medium-sized mammals and birds were far less important as potential prey, and plant material contributed considerably to the diet of the raccoon dog only. Foxes widely scavenged on ungulates carcasses.

When Shannon's index of diversity $\bar{H}$ of the diets of five species are compared (Table 1) the wolf and the lynx appeared as specialists, whereas the other three species proved to be generalists.

A comparison of the winter and spring diets of the fox and marten showed little variation (Table 2). Both species ceased the consumption of medium-sized mammals towards spring, and preyed more on small mammals, mainly rodents. However, the differences were significant only in the case of the marten $(p<0.001$ for the small mammals group, $p<0.01$ for the medium-sized mammals. $G$-test for independence).

\subsection{Sharing of Food Resources}

Ungulates and small mammals (mainly rodents) made up $85.6 \%$ of the total biomass consumed by the five species (Fig. 1). Medium-sized mammals add to this figure by $5.8 \%$. Therefore, $91.4 \%$ of the biomass consumed was provided exclusively by mammals. The relative contribution of each species of predators to the utilization of the main food groups is shown in Fig. 1. Generalistic species (especially fox and marten) used all resources available, whereas specialists contributed markedly to the consumption of fewer food classes. 


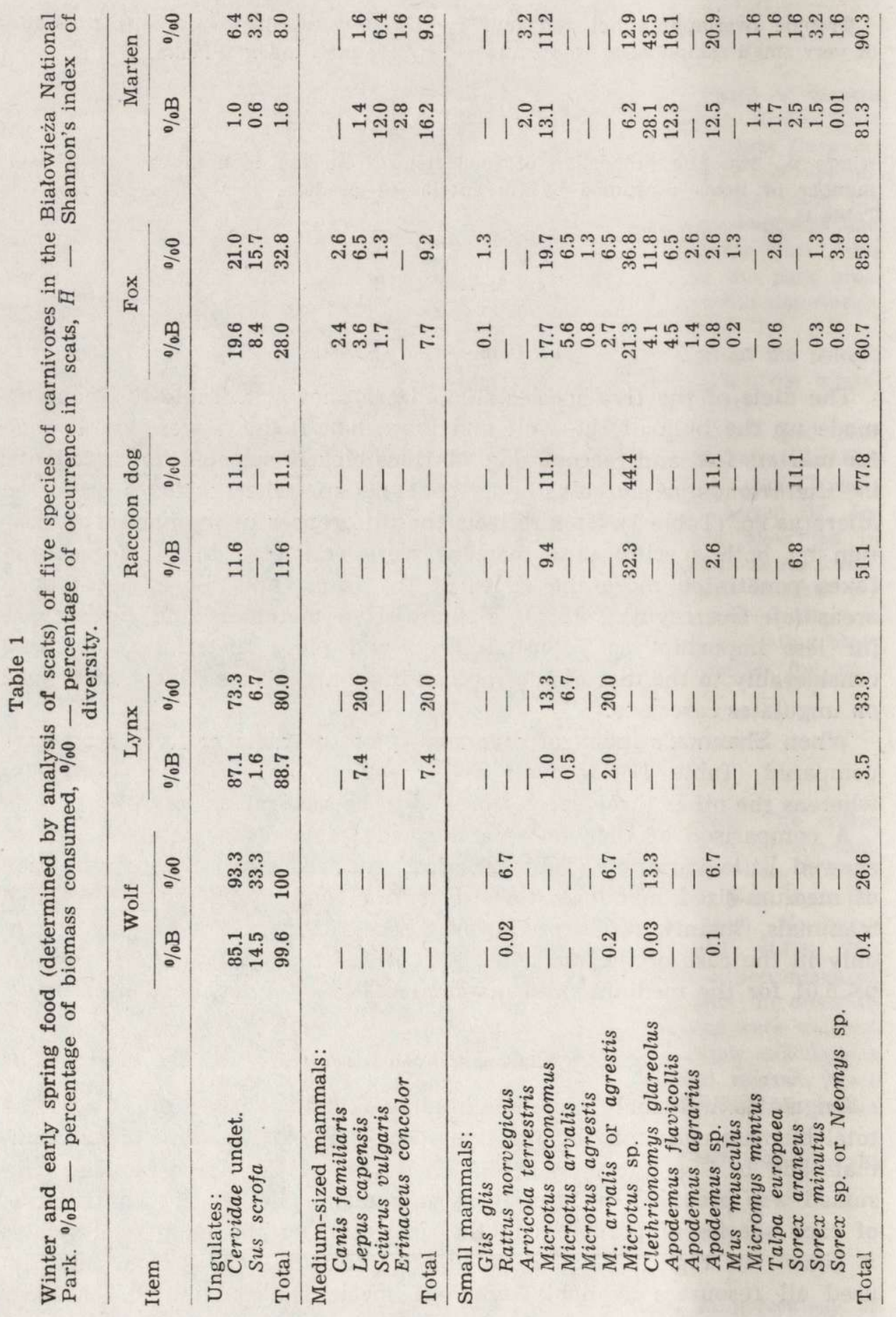




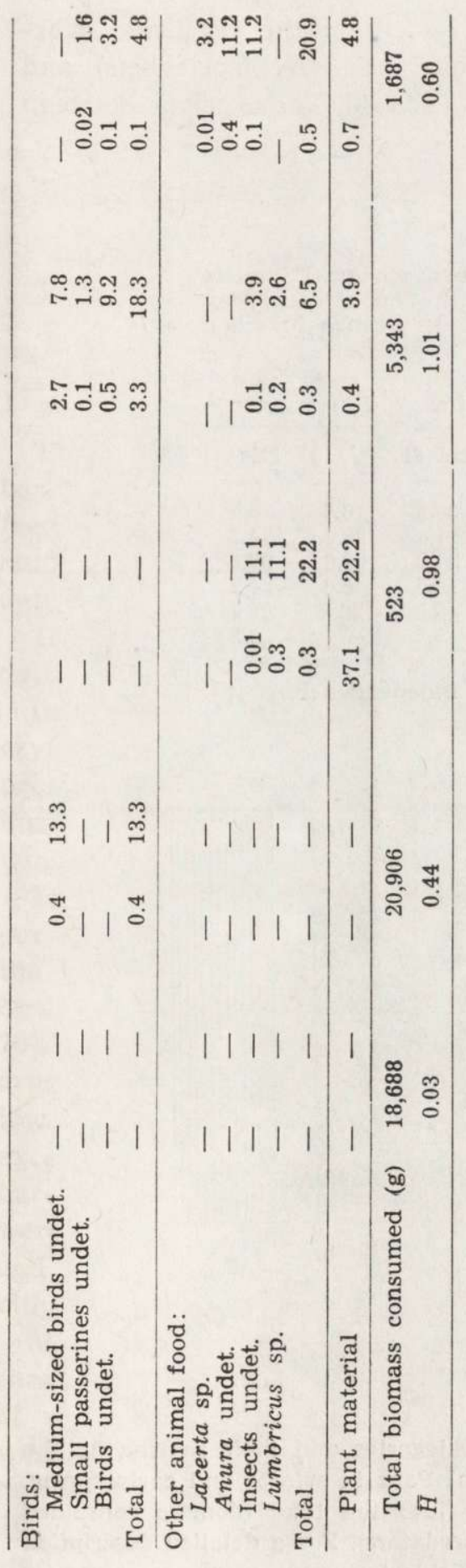


Common use of the same resources decided on the extensive overlapping of food niches between the wolf and lynx (specialists) and between the marten and fox (generalists) (Table 3). The overlaps between specialists and generalists were smaller.

Table 2

Comparison of winter (W) and early spring (ES) diets of foxes and pine martens. Contribution of each prey class expressed as percantage of occurrence in scats. Numbers of scats given in brackets.

\begin{tabular}{lrrrrr}
\hline \multirow{2}{*}{ Prey class } & \multicolumn{2}{c}{ Red fox } & & \multicolumn{2}{c}{ Pine marten } \\
\cline { 2 - 3 } \cline { 5 - 6 } & W (35) & ES (41) & & W (15) & ES (47) \\
\hline Ungulates & 28.5 & 36.5 & 6.6 & 8.5 \\
Medium-sized mammals & 14.2 & 4.8 & & $26.6^{1}$ & 4.2 \\
Small mammals & 80.0 & 90.2 & & $66.6^{2}$ & 97.8 \\
Birds & 17.1 & 19.5 & 6.6 & 4.2 \\
Other animal food & 5.7 & 7.3 & 26.6 & 19.1 \\
Plant material & - & 7.3 & - & 6.3 \\
\hline
\end{tabular}

${ }^{1} p<0.01, \quad{ }^{2} p<0.001$, G-test for independence.

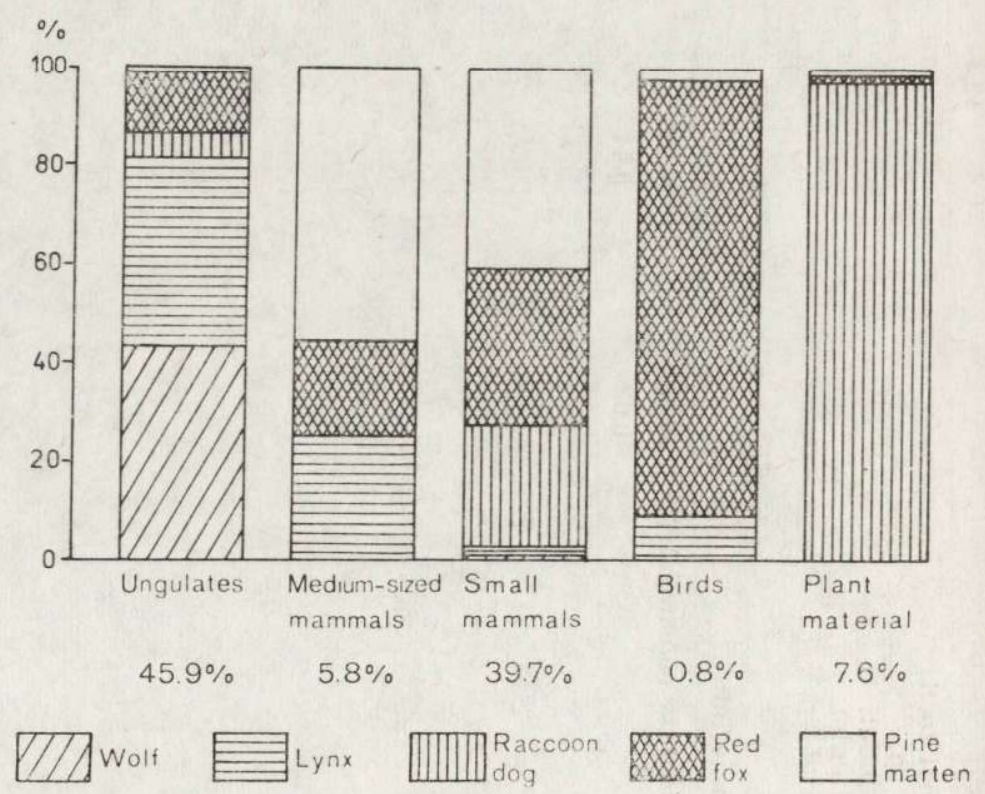

Fig. 1. Relative importance of the main food categories and their sharing by the five species of carnivores in Bialowieża National Park in winter and early spring. Percentages show contribution of food classes into the total biomass consumed (taking $100 \mathrm{~g}$ representative of each species of predators). For a detailed description of food classes see Table 1 . 
Table 3

Food overlapping (expressed as Pianka's index $\alpha$ ) between four species of carnivores in winter and early spring. Index $\alpha$ varies from 0 (complete isolation) to 1 (identity of utilized resources).

\begin{tabular}{lcccc}
\hline & Marten & Red fox & Lynx & Wolf \\
\cline { 2 - 5 } Marten & $*$ & 0.94 & 0.44 & 0.23 \\
Red fox & & $*$ & 0.68 & 0.57 \\
Lynx & & & $*$ & 0.96 \\
\hline Mean $\alpha$ & 0.54 & 0.73 & 0.69 & 0.57 \\
\hline
\end{tabular}

\section{DISCUSSION}

The data on the diets of the wolf, lynx, and raccoon dog, though based on very small samples, gave an insight into the winter and spring feeding habits of these predators in Polish lowland forests. Further studies are, however, needed to elucidate the trophic role of these predators in the community of vertebrates.

The results on marten and fox diets allow some comparison with the data from other regions of Poland.

In contrary to other areas where large predators were absent (Goszczyński, 1974, 1986) the foxes in the Białowieża forest had well pronounced scavenging habits. They fed on the wolves and lynxes kills, but also utilized the carcasses of ungulates that had died from severe winter conditions.

The surprisingly large proportion of rodents in the diet of foxes in our study might be a result of both the high numbers of rodents during the study period, and the scarcity of alternate prey such as hares and birds. In the agrocenoses of western Poland (Goszczyński, 1974) up to $70 \%$ of biomass consumed by foxes was made up by field voles Microtus arvalis during the peak numbers of this rodent. When voles were in low numbers the contribution of this prey to the fox diet did not exceed $20 \%$, and the predators compensated their lack by hunting more hares and birds. The most common avian prey of foxes in rural settings were pheasants Phasianus colchicus, domestic hens Gallus domesticus, and partridges Perdix perdix (Goszczyński, 1974, 1986). All these were either scarce or absent from our study area.

Martens in the Białowieża forest hunted less hares and birds, and consumed much less plant material than reported from agricultural areas of western Poland (Goszczński, 1976) and from managed forests and woodlots of central Poland (Goszczyński, 1986). It must be kept in mind, however, that the analysis of martens' scats from those areas did not allow a separation between co-occurring $M$. martes and $M$. foina. In our study area, forest rodents were the basic food of martens. Again, it 
seems to reflect the differences in prey numbers and availability between the regions under comparison. The low amount of plant material in martens' diet as compared especially to agricultural ecosystems (Goszczyński, 1976) might be due to the very deep snow, covering the edible fruits during the whole, winter, and also the different species composition of fruit-bearing shrubs and trees. Malus sp., Pirus sp., and Rosa canina that were in rich supply elsewhere might occur only sporadically in our study forest.

Data given by Rzebik-Kowalska (1972) for foxes and martens collected throughout Poland are different from our results in a similar manner as the above cited results of Goszczyński's works. Closer comparisons, however, are not possible due to differences in methods employed by us and by Rzebik-Kowalska (analysis of stomachs).

Further studies on predators in the Białowieża National Park, the well preserved forest with almost no human alteration, should give insight into the feeding habits of these species in their ancestral habitats.

Acknowledgments: We thank the MRI's technicians who helped us in collecting scats (M. Szlachciuk and J. Siemieniuk) and analyzing them (Mrs. N. Wojcieszuk). Dr. J. Goszczyński provided stimulating discussions at all stages of the work. The senior author (SR) benefited from a UNESCO/Polish Academy of Sciences fellowship held at the Mammals Research Institute.

\section{REFERENCES}

1. Andersson M. \& Erlinge S., 1977: Influence of predation on rodent population. Oikos, 29: 591-597.

2. Dziurdzik B., 1973: Key to the identification of hairs of mammals from Poland Acta zool. cracov. 18: 73-91.

3. Erlinge S., Göransson G., Hansson L., Hogstedt G., Liberg O., Nilsson I. N., Nilsson T., Schantz T. von \& Sylvén M., 1983: Predation as a regulating factor on small rodent populations in Southern Sweden. Oikos, 40: 36-52.

4. Faliński J. B., 1986: Vegetation dynamics in temperate lowland primeval forests. Dr W. Junk Publishers, Dordrecht. 1-537.

5. Goszczyński J., 1974: Studies on the food of foxes. Acta theriol., 19: 1-18.

6. Goszczyński J., 1976: Composition of the food of martens. Acta theriol., 21: $527-534$.

7. Goszczyński J., 1985: The effect of structural differentiation of ecological landscape on the predator-prey interaction. Publications of Warsaw Agricultural University SGGW-AR. 1-80. [In Polish with English summary]

8. Goszczyński J., 1986: Diet of foxes and martens in Central Poland. Acta theriol., 31: 491-506.

9. Guitian J. \& Callejo A., 1983: Structure d'une communaute de Carnivores dans la Cordillère Cantabrique occidentale. Rev. Ecol. (Terre et Vie), 37: 145-160.

10. Lockie J. W., 1959: The estimation of the food of foxes. J. Wildl. Manage., 23: $224-227$.

11. Pianka E. R., 1973: The structure of lizard communities. Ann. Rev. Ecol. Syst., 4: $53-74$. 
12. Ryszkowski L., Goszczyński J. \& Truszkowski J., 1973: Trophic relationships of the common vole in cultivated fields. Acta theriol., 18: 125-165.

13. Ryszkowski L., Wagner C. K., Goszczyński J. \& Truszkowski J., 1971: Operation of predators in a forest and cultivated fields. Ann. Zool. Fennici, 8: $160-168$.

14. Rzebik-Kowalska B., 1972: Studies on the diet of the carnivores in Poland. Acta zool. cracov., 19: 415-506. [In Polish with English summary].

15. Shannon C. E. \& Weaver W., 1949: The mathematical theory of communication. Univ. Illinois Press. $1-320$.

Received 20 August 1987, Accepted 19 October 1987.

\section{Santiago REIG i Włodzimierz JĘDRZEJEWSKI}

\section{ZIMOWY I WCZESNO-WIOSENNY SKLAD POKARMU NIEKTORYCH DRAPIEŻNIKOW W BIALOWIESKIM PARKU NARODOWYM}

\section{Streszczenie}

Prezentowane są wyniki analizy łącznie 177 porcji kału rysia, wilka, jenota, lisa i kuny leśnej, zebranych w Białowieskim Parku Narodowym od grudnia 1985 do maja 1986. Najczęstszym pokarmem byly kopytne (Cervidae i Sus scrofa) oraz gryzonie (Clethrionomys glareolus, Apodemus sp., i Microtus sp.). Są to równocześnie najliczniejsze grupy ofiar w tym okresie. Badane ssaki drapieżne można podzielić na dwie kategorie: 1. gatunki wyspecjalizowane (wilk i ryś) polujące na kopytne; 2. gatunki niewyspecjalizowane (jenot, lis, kuna) odżywiające się przede wszystkim gryzoniami (Ryc. 1, Tabela 1). Lisy częściej chwytały gatunki gryzoni żyjące w otoczeniu BPN (środowiska polne, ląkowe i bagienne). Kuny odgrywały większą rolę jako drapieżniki gryzoni leśnych. Bardzo mała liczebność populacji zajęcy i ptaków w tym okresie sprawiła, że w porównaniu z innymi regionami Polski oba omawiane gatunki drapieżników w większym stopniu zjadały gryzonie, a lis także padlinę. 